\title{
Differences in association of lower bone mineral density with higher coronary calcification in female and male end-stage renal disease patients
}

Zhimin Chen ${ }^{1,2^{*}}$, Abdul Rashid Qureshi ${ }^{2}$, Torkel B. Brismar ${ }^{3}$, Jonaz Ripsweden ${ }^{3}$, Mathias Haarhaus ${ }^{2}$ Peter Barany ${ }^{2}$, Olof Heimburger ${ }^{2}$, Bengt Lindholm² and Peter Stenvinkel ${ }^{2}$

\begin{abstract}
Background: Risk of cardiac events and cardiovascular disease (CVD) in end-stage renal disease (ESRD) patients are predicted by coronary artery calcification (CAC) independently. It is not clear to what extent low bone mineral density (BMD) is associated with higher risk of CAC and if sex interacts. We investigated the sex-specific associations of CAC score with total body BMD (tBMD) as well as with BMD of different skeletal sub-regions.

Methods: In 174 ESRD patients, median age 57 (10th-90th percentiles 29-75) years, 63\% males, BMD (measured by dual-energy X-ray absorptiometry; DXA), CAC score (measured by cardiac CT) and circulating inflammatory biomarkers were analysed.

Results: A total of 104 (60\%) patients with CAC > 100 AUs were older, had higher prevalence of both clinical CVD and diabetes, higher level of high sensitivity C-reactive protein, tumour necrosis factor, interleukin-6 and lower T-score of tBMD. Female patients had significantly lower tBMD and BMD of all skeletal sub-regions, except head, than male patients. Female patients with high CAC (> $100 \mathrm{AUs}$ ) had significantly decreased T-score of tBMD, and lower BMD of arms, legs than those low CAC ( $\leq 100$ AUs); elevated CAC score were associated with tBMD, T-score, Z-score of tBMD and BMD of arms and legs, while no such differences was observed in males. Multivariate generalized linear model (GLM) analysis adjusted for age, diabetes and hsCRP showed that in females per SD higher CAC score (1057 AUs) was predicted by either per SD $\left(0.13 \mathrm{~g} / \mathrm{cm}^{2}\right)$ lower tBMD or per SD $\left(0.17 \mathrm{~g} / \mathrm{cm}^{2}\right)$ lower BMD at legs. No such associations were found in male ESRD patients.
\end{abstract}

Conclusions: In female, but not male, lower BMD, in particular sub-regions of legs, was associated with higher CAC score independently. Low BMD has the potential to identify increased risk for high CAC score in ESRD patients.

Keywords: Bone mineral density, Coronary calcification, End-stage renal disease

\footnotetext{
* Correspondence: zhiminchen@zju.edu.cn

${ }^{1}$ Kidney Disease Center, The First Affiliated Hospital, College of Medicine,

Zhejiang University, Hangzhou, China

${ }^{2}$ Division of Renal Medicine and Baxter Novum, Department of Clinical

Sciences, Intervention and Technology, Karolinska Institutet, Stockholm,

Sweden

Full list of author information is available at the end of the article
}

(c) The Author(s). 2019 Open Access This article is distributed under the terms of the Creative Commons Attribution 4.0 International License (http://creativecommons.org/licenses/by/4.0/), which permits unrestricted use, distribution, and reproduction in any medium, provided you give appropriate credit to the original author(s) and the source, provide a link to the Creative Commons license, and indicate if changes were made. The Creative Commons Public Domain Dedication waiver (http://creativecommons.org/publicdomain/zero/1.0/) applies to the data made available in this article, unless otherwise stated. 


\section{Background}

Cardiovascular disease (CVD) is a main cause of morbidity and mortality of end-stage renal disease (ESRD) patients [1] and the risk of CVD is predicted by coronary artery calcification $(\mathrm{CAC})$ independently in ESRD patients $[2,3]$. Thus, CAC can be an independent risk factor of CVD beyond conventional risk factors $[4,5]$. In ESRD patients, chronic kidney disease (CKD) - mineral and bone disorders (CKD-MBD) is a major complication. Decreased bone mineral density (BMD) associates with increased fracture risk and predicts higher mortality and cardiovascular events in CKD patients and the general population [6-8]. Low BMD is associated with higher risk of CVD $[6,9,10]$.

Bone mineralization and vascular calcification share some common pathways [11, 12]. An association of reduced BMD with vascular calcification has been found in the general population $[13,14]$ as well as in ESRD patients $[15,16]$. However, no such association was found in some other studies in the general population [17-20] and ESRD patients [21]. Decreased cortical bone density has been found to associate with CAC [22], and progression of CAC was predicted by osteoporosis [23] in dialysis patients. Several molecular mechanisms have been suggested for the link between bone metabolism and vascular calcification [24].

Since it is not clear to what extent a decreased BMD may be linked to increased risk of CAC and other manifestations in ESRD patients, we investigated sex-specific associations between total body BMD (tBMD) and BMD of different skeletal sub-regions, determined by dual-energy X-ray absorptiometry (DXA), and CAC, determined by computed tomography $(\mathrm{CT})$ of the heart.

\section{Methods}

\section{Patients}

One hundred seventy-four ESRD patients with median age of 57 (10th-90th percentiles 29-75) years, 63\% males were enlisted at the Department of Renal Medicine at Karolinska University Hospital at Huddinge, Stockholm, between March 2008 and June 2015. All patients from three different cohorts, who had undergone both coronary CT and DXA measurements, were included, 69 (40\%) were incident dialysis patients, 67 (38\%) prevalent peritoneal dialysis (PD) patients and 38 (22\%) recipients of living donor kidney transplant (LD-Rtx). The Ethics Committee of Karolinska University Hospital Huddinge approved the study protocols. Informed consent in written was obtained from all patients. Baseline characteristics of the 174 included ESRD patients are outlined in Table 1.

\section{Measurements of BMD}

BMD was measured by dual-energy X-ray absorptiometry (DXA) [25] and was presented in $\mathrm{g} / \mathrm{cm}^{2}$ or
T-score (i.e. the number of standard deviations difference in BMD compared to young adults of the same gender) or Z-score (indicating the number of standard deviations difference in BMD compared to an age-matched reference population of the same gender)). DXA was performed in all 174 patients using a DPX-L device (GE Lunar iDXA with software enCore 2008 version 12, 30, 008, GE Medical systems, Chalfont St. Giles, UK). BMD of total body (tBMD) and several skeletal sub-regions were also obtained: head, arms, legs, trunk, ribs, spine and pelvis.

\section{Measurements of CAC}

CAC was measured by $\mathrm{CT}$, a non-invasive approach, performed on a 64-channel detector scanner (LightSpeed VCT; General Electric (GE) Healthcare, Milwaukee, WI, USA) in cine mode. CAC was quantified in Agatston units (AUs) as a lesion with an area $>1 \mathrm{~mm}^{2}$ and a peak intensity > 130 Hounsfield Units (HUs) based on the Agatston method previously described in detail [26]. Details of CAC scan ascertainment and quantification have been published [27-29] in our previous study. In this study, we used a CAC score $>100$ AUs which was associated with an higer risk of myocardial ischaemia and cardiac events [30] to identify patients with definite to extensive plaque burden.

\section{Laboratory analysis and other measurements}

Plasma blood samples were received after an overnight fast in the morning in the ESRD patients. If not analysed immediately, the samples were kept frozen at $-70^{\circ} \mathrm{C}$. Plasma tumour necrosis factor (TNF), interleukin-6 (IL-6) and total testosterone concentrations were tested by commercial kits according to the instructions of the manufacturer available for an Immulite Automatic Analyzer (Siemens Medical Solutions, Los Angeles, CA, USA). Pentraxin-3 (PTX3) was tested by ELISA kits of R\&D systems (Abingdon, UK). The level of haemoglobin, serum creatinine, triglycerides, cholesterol, and high density lipoprotein (HDL)-cholesterol, calcium, phosphorus, intact parathyroid hormone (iPTH), 25(OH) and $1,25(\mathrm{OH})_{2}$ vitamin $\mathrm{D}_{3}$, and high-sensitivity C-reactive protein (hsCRP) were tested by routine methods at the Department of Laboratory Medicine, Karolinska University Hospital, Huddinge, Sweden.

At the baseline body mass index (BMI) was recorded according to height and body weight. Arterial systolic and diastolic blood pressures (BP) were measured three times after a 15 -min resting period in the morning. Earlier or present occurrence of documented of cerebrovascular, cardiovascular, or peripheral vascular disease like patients had suffered from cerebrovascular disease (stroke), myocardial 
Table 1 Clinical and biochemical characteristics for the total 174 ESRD patients and for two subgroups based according to CAC score

\begin{tabular}{|c|c|c|c|c|}
\hline & $\begin{array}{l}\text { Total patients } \\
n=174\end{array}$ & $\begin{array}{l}\text { Low CAC } \\
(\leq 100 \mathrm{AUs}) \\
(n=70)\end{array}$ & $\begin{array}{l}\text { High CAC } \\
(>100 \mathrm{AUs}) \\
(n=104)\end{array}$ & $P$ value \\
\hline \multicolumn{5}{|l|}{ Demography and metabolic biomarkers } \\
\hline Age, years & $57(29,75)$ & $41(23,63)$ & $64(49,78)$ & $<0.001$ \\
\hline Male, \% & 63 & 57 & 67 & 0.173 \\
\hline Diabetes, \% & 28 & 10 & 40 & $<0.001$ \\
\hline$C V D, \%$ & 22 & 3 & 36 & $<0.001$ \\
\hline Body mass index, $\mathrm{kg} / \mathrm{m}^{2}$ & $24.8(19.9,30.8)$ & $23.9(19.7,30.7)$ & $25.2(20.7,30.8)$ & 0.080 \\
\hline Systolic BP, mmHg & $139(114,169)$ & $135(114,163)$ & $143(113,179)$ & 0.024 \\
\hline Diastolic BP, mmHg & $83(67,97)$ & $85(70,100)$ & $81(66,96)$ & 0.123 \\
\hline Hemoglobin, g/L & $114(94,130)$ & $113(92,128)$ & $114(100,130)$ & 0.064 \\
\hline Triglycerides, mmol/L & $1.6(0.9,3.0)$ & $1.6(0.9,2.8)$ & $1.4(0.9,3.6)$ & 0.039 \\
\hline Cholesterol, mmol/L & $4.7(3.3,6.6)$ & $4.6(3.4,6.1)$ & $4.6(3.0,5.7)$ & 0.175 \\
\hline HDL-cholesterol, mmol/L & $1.2(0.8,2.3)$ & $1.4(0.9,2.4)$ & $1.1(0.9,2.3)$ & 0.373 \\
\hline Creatinine, $\mu \mathrm{mol} / \mathrm{L}$ & $727(491,1012)$ & $738(509,1185)$ & $729(414,981)$ & 0.014 \\
\hline S-albumin, g/L & $33(26,39)$ & $35(28,40)$ & $32(23,38)$ & 0.001 \\
\hline hsCRP, mg/L & $2.1(0.4,18.7)$ & $1.2(0.2,9.1)$ & $3.6(0.8,35.4)$ & 0.003 \\
\hline$T N F, p g / m^{a}$ & $15.3(9.9,20.4)$ & $12.9(8.0,19.8)$ & $16.7(12.0,20.7)$ & 0.003 \\
\hline $\mathrm{IL}-6, \mathrm{pg} / \mathrm{ml}^{\mathrm{b}}$ & $4.5(0.9,14.9)$ & $2.1(0.4,8.1)$ & $6.9(2.2,20.5)$ & $<0.001$ \\
\hline PTX3 ng/mL ${ }^{c}$ & $1.7(0.7,6.2)$ & $1.8(0.6,7.1)$ & $1.7(0.7,7.1)$ & 0.758 \\
\hline Total testosterone in male, $\mathrm{nmol} / \mathrm{L}^{\mathrm{d}}$ & $11.0(5.8,20.5)$ & $12.2(7.4,25.6)$ & $10.2(4.7,16.9)$ & 0.025 \\
\hline \multicolumn{5}{|l|}{ Mineral bone disease biomarkers } \\
\hline iPTH, ng/L & $300(96,655)$ & $265(113,658)$ & $320(79,735)$ & 0.595 \\
\hline Calcium, mmol/L & $2.3(2.0,2.5)$ & $2.3(2.1,2.5)$ & $2.2(1.9,2.6)$ & 0.924 \\
\hline Phosphate, mmol/L & $1.8(1.2,2.5)$ & $1.9(1.2,2.4)$ & $1.8(1.2,2.6)$ & 0.559 \\
\hline 1,25-OH vitamin $\mathrm{D}, \mathrm{nmol} / \mathrm{L}^{\mathrm{e}}$ & $13(9,28)$ & $16.5(9,34)$ & $11(9,23)$ & 0.054 \\
\hline $25-\mathrm{OH}$ vitamin $\mathrm{D}, \mathrm{ng} / \mathrm{L}^{f}$ & $29(13,70)$ & $33(14,57)$ & $29(14,80)$ & 0.861 \\
\hline $\mathrm{tBMD}, \mathrm{g} / \mathrm{cm}^{2}$ & $1.12(0.92,1.30)$ & $1.13(1.00,1.31)$ & $1.10(0.91,1.27)$ & 0.095 \\
\hline T-score of tBMD & $-0.8(-2.7,1.1)$ & $-0.6(-2.0,1.2)$ & $-1.1(-3.1,1.1)$ & 0.006 \\
\hline Z-score of tBMD & $-0.4(-1.8,1.2)$ & $-0.1(-1.5,1.1)$ & $-0.5(-2.4,1.3)$ & 0.097 \\
\hline
\end{tabular}

Data presented as median (range of 10th - 90th percentile) or percentage

Abbreviations: $B P$ blood pressure, $H D L$ high-density lipoprotein, $h S C R P$ high sensitivity C-reactive protein, TNF tumor necrosis factor, lL-6 interleukin-6, $P T X$ pentraxin, $i P T H$ intact parathyroid hormone, $C A C$ coronary artery calcification, $t B M D$ total bone mineral density

${ }^{\mathrm{a}} n=151,{ }^{\mathrm{b}} n=166,{ }^{\mathrm{c}} n=135 ;{ }^{\mathrm{d}} n=95 ;{ }^{\mathrm{e}} n=130,{ }^{\mathrm{f}} \mathrm{n}=105$

infarctions, clinical signs of ischemic heart disease (angina pectoris), peripheral ischemic atherosclerotic vascular disease, had a history of an aortic aneurysm, mitral stenosis, and cardiac failure, considered as signs of CVD and details of CVD event determination have been published [31].

\section{Statistical analysis}

Data are presented as median (range of 10th to 90th percentile) or percentage, as appropriate. Comparisons between two groups were assessed by the non-parametric Wilcoxon test for continuous variables and Fischer's exact test for categorical variables.
Spearman rank correlation analysis was used to determine associations between selected parameters. A receiver operating characteristics (ROC) curve was plotted for T-score of tBMD, age and hsCRP in relation to presence of high CAC score (>100 AUs). To study the associations between BMD, CAC score and other parameters, a multivariable generalized linear model (GLM) analysis were performed. In GLM analysis (stratified by gender), age, diabetes and hsCRP were included in the model. Statistical analyses were performed using statistical software SAS version 9.4 (SAS Campus Drive, Cary, NC, USA). Statistical significance was set at the level of $p<0.05$. 


\section{Results}

\section{Clinical and biochemical characteristics of these ESRD} patients

Demographics and clinical characteristics of 174 ESRD patients are shown in Table 1; A total of 104 (60\%) patients had CAC >100 AUs. As expected, patients with high CAC (> 100 AUs) were older, higher prevalence of clinical CVD and diabetes, had higher levels of systolic BP, hsCRP, TNF, IL-6 and, lower levels of triglycerides, creatinine, serum albumin, total testosterone in male,and T-score of tBMD (Table 1). In receiver-operator characteristics curve (ROC) analysis, high CAC (>100 AUs) was associated with age (AUC, 0.89), hsCRP (AUC, 0.74) and T-score of tBMD (0.38) (Fig. 1). When placed into two subgroups based on the median of tBMD level, are shown in Additional file 1: Table S1. Patients with tBMD lower than median $\left(\leq 1.117 \mathrm{~g} / \mathrm{cm}^{2} ; n=87\right)$ had lower prevalence of male, lower BMI, creatinine, phosphate and higher concentration of HDL than those with $\mathrm{HBMD}$ higher than median $\left(>1.117 \mathrm{~g} / \mathrm{cm}^{2} ; \mathrm{n}=87\right)$. No statistically significant differences were observed in any of the other variables (Additional file 1: Table S1).

\section{Differences of BMD in female and male ESRD patients}

Female ESRD patients had significantly lower tBMD and BMD of all skeletal sub-regions, except head, than male patients (Fig. 2). Female patients with high CAC (>100 AUs) had significantly decreased T-score of tBMD and sub-regions BMD including armsand legs than patients

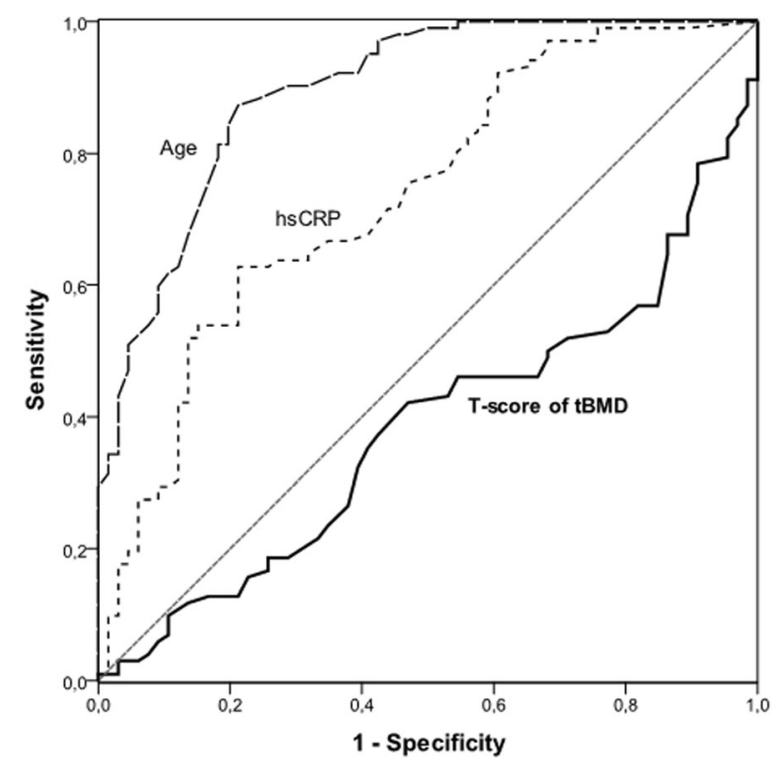

Fig. 1 Areas under the curves (AUC) of receiver-operating characteristics curve (ROC) analysis for T-score of tBMD, age and hsCRP in relation to presence of high CAC score (>100 AUs). The separate AUCs are as follows: AUC of age (0.89), hsCRP (0.74) and T-score of tBMD (0.38) with low CAC ( $\leq 100$ AUs) (Table 2). No such differences were observed in males (Table 2).

\section{Univariate correlation analysis of CAC score in relation to BMD}

In Spearman rank correlation analysis, CAC score correlated with age (Fig. 3a), diabetes (rho $=0.35, p<0.001$ ), CVD (rho $=0.45, p<0.001$ ), BMI (rho $=0.18, p=0.017$ ), HDL-cholesterol (rho $=-0.18, \quad p=0.019), \quad 1,25-\mathrm{OH}$ vitamin $\mathrm{D}$ (rho $=-0.30, p<0.001)$, albumin $($ rho $=-$ $0.24, p=0.001$ ) and inflammatory biomarkers: hsCRP (rho $=0.40, p<0.001)$, IL-6 (rho $=0.51, p<0.001)$ and TNF (rho $=0.39, p<0.001$ ) significantly. An inverse correlation between $\mathrm{CAC}$ score and total testosterone was found in 95 males (Fig. 3b).

Higher CAC score was associated with tBMD (Fig. 3c), T-score and Z-score of $\mathrm{tBMD}$, and sub-regions BMD of arms and legs (Fig. 3d) in females (Table 3). In males, elevated CAC score was only associated with BMD at head (Table 3).

\section{Multivariate generalized linear regression analysis of predictors of CAC score}

In multivariate GLM analysis adjusted for age, diabetes and hsCRP found that patients one SD (1057 AUs) higher CAC score was predicted independently by either one SD $\left(0.17 \mathrm{~g} / \mathrm{cm}^{2}\right)$ lower BMD at the legs (Table 4) or one SD $\left(0.13 \mathrm{~g} / \mathrm{cm}^{2}\right)$ lower tBMD (Table 5$)$ in female ESRD. No such associations were found in male ESRD patients in whom one SD (1484 AUs) higher CAC score was independently predicted by one SD (16 years) higher age (Table 6 and Table 7 ).

When total testosterone in 95 males was added to the model, 1-SD higher BMD at legs (Table 6) but not 1-SD higher tBMD (Table 7) was associated with 1-SD higher CAC score independently.

\section{Discussion}

To the best of our knowledge, this is the first study investigating how sex affects the associations of BMD of different skeletal sub-regions with CAC score in ESRD. Our main observation is that lower tBMD and lower BMD of skeletal sub-regions, in particular at sub-regions of the legs, were associated with increased CAC score independently in females only.

Since several epidemiological studies demonstrated coexistence, but no independent association, of vascular calcification with reduced BMD, it has been proposed that these conditions represent two independent age-related processes $[32,33]$. Although they are pathogenically connected $[13,34,35]$, the detailed mecha$\operatorname{nism}(\mathrm{s})$ for the relationship between vascular calcification and BMD are still unclear. Low BMD is associated with an increased risk of CVD $[6,10,36]$ and 


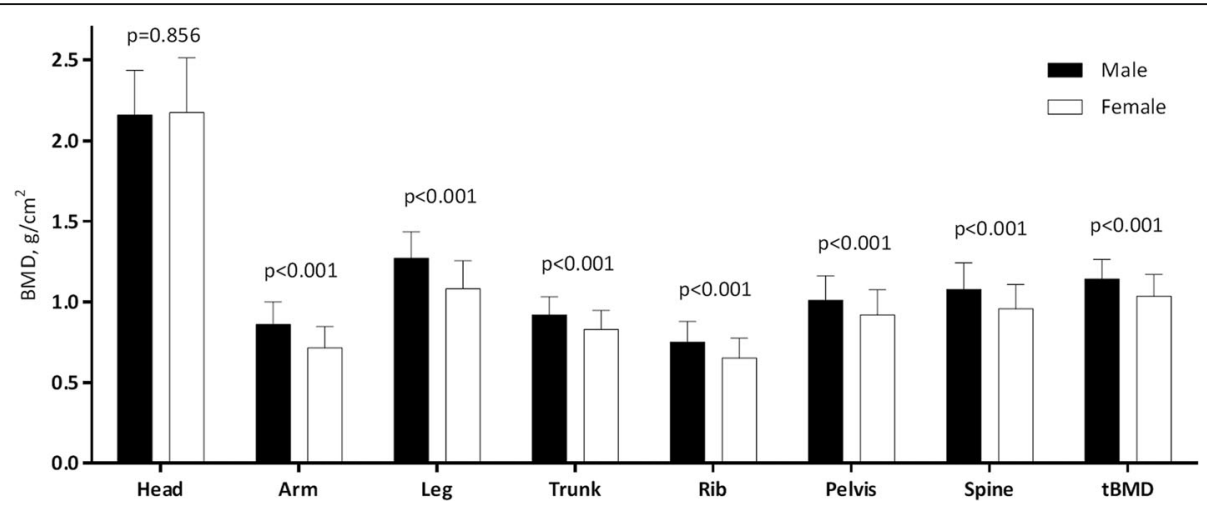

Fig. 2 Differences of BMD at sub-regions and total BMD (tBMD) in male and female ESRD patients

predicts cardiac events and increased mortality in CKD patients and the general population [6-8]. Low BMD and vascular calcification are both common features of the uremic phenotype [37]. Kim et al. [18] found - in a statistical model stratified by gender - when adjusting for age and comorbid conditions, there is no significant association of BMD with CAC. We report that in females, whereas lower BMD, in particular sub-regions of legs, was associated with a higher CAC score independently, even after adjustment for age, diabetes and hsCRP. No such associations were observed in males. Our observation that sex should be taken into consideration when links between bone health and vascular calcification are assessed corresponds with other reports showing associations between lower BMD and presence of CAC in ESRD $[6,9,10]$.

It is not known which specific bone location is optimal when studying links between BMD and vascular calcification. It is not evident how one should interpret our observation that tBMD and in particular BMD of legs rather than BMD of other central locations was associated to CAC score. In non-renal patients, lower BMD of the spine, but not the hip [14], was associated with aortic calcification independently. In contrast, Disthabanchong et al. [7] found that in haemodialysis patients, CAC was negatively associated with BMD of hip but not with BMD of lumbar spine. Uyama et al. [35] found an inverse correlation between carotid plaque score and $\mathrm{BBMD}$, but no association with BMD of lumbar spine. Banks et al. [34] found in women that reduced BMD of the proximal femur associated with aortic calcification. Kohno et al. [38] reported in male HD patients association of more bone loss of the ultra-distal radius with higer mortality. Those inconsistent results may be related to differences in population demographics, methods and anatomical sites of measurement of vascular calcification. Nevertheless, in this study, when examining BMD by DXA of different skeletal sub-regions, the correlation between BMD and $\mathrm{CAC}$ was more significant in legs than the spine. Since

Table 2 BMD at sub-regions and total BMD (tBMD) in low and high CAC groups stratified by gender

\begin{tabular}{|c|c|c|c|c|c|c|}
\hline & \multicolumn{3}{|l|}{ Female } & \multicolumn{3}{|l|}{ Male } \\
\hline & $\begin{array}{l}\text { Low CAC } \\
(\leq 100 \mathrm{AUS}) \\
(n=30)\end{array}$ & $\begin{array}{l}\text { High CAC } \\
(>100 \mathrm{AUs}) \\
(n=34)\end{array}$ & $\overline{p \text {-value }}$ & $\begin{array}{l}\text { Low CAC } \\
(\leq 100 \mathrm{AUS}) \\
(n=40)\end{array}$ & $\begin{array}{l}\text { High CAC } \\
(>100 A \cup s) \\
(n=70)\end{array}$ & $p$-value \\
\hline Head, $\mathrm{g} / \mathrm{cm}^{2}$ & $2.19(1.94,2.65)$ & $2.11(1.73,2.66)$ & 0.162 & $2.25(1.90,2.60)$ & $2.13(1.73,2.45)$ & 0.023 \\
\hline Arms, $\mathrm{g} / \mathrm{cm}^{2}$ & $0.73(0.63,1.01)$ & $0.68(0.49,0.82)$ & 0.029 & $0.86(0.71,1.09)$ & $0.84(0.67,1.01)$ & 0.233 \\
\hline Legs, $\mathrm{g} / \mathrm{cm}^{2}$ & $1.16(0.95,1.30)$ & $1.02(0.78,1.26)$ & 0.012 & $1.29(1.06,1.52)$ & $1.24(1.03,1.45)$ & 0.239 \\
\hline Trunk, $\mathrm{g} / \mathrm{cm}^{2}$ & $0.83(0.69,1.00)$ & $0.82(0.66,1.00)$ & 0.439 & $0.90(0.79,1.06)$ & $0.91(0.75,1.09)$ & 0.742 \\
\hline Ribs, $\mathrm{g} / \mathrm{cm}^{2}$ & $0.66(0.50,0.87)$ & $0.62(0.50,0.88)$ & 0.480 & $0.75(0.59,0.89)$ & $0.74(0.59,0.97)$ & 0.797 \\
\hline Pelvis, $\mathrm{g} / \mathrm{cm}^{2}$ & $0.94(0.73,1.15)$ & $0.88(0.71,1.13)$ & 0.130 & $1.02(0.83,1.26)$ & $1.00(0.81,1.20)$ & 0.217 \\
\hline Spine, $\mathrm{g} / \mathrm{cm}^{2}$ & $0.92(0.78,1.20)$ & $0.97(0.70,1.11)$ & 0.989 & $1.04(0.87,1.26)$ & $1.08(0.86,1.35)$ & 0.450 \\
\hline $\mathrm{tBMD}, \mathrm{g} / \mathrm{cm}^{2}$ & $1.07(0.93,1.20)$ & $0.99(0.83,1.20)$ & 0.055 & $1.16(1.03,1.33)$ & $1.12(0.96,1.31)$ & 0.143 \\
\hline T-score of tBMD & $-0.5(-2.0,0.9)$ & $-1.5(-3.5,1.1)$ & 0.021 & $-0.8(-2.2,1.3)$ & $-0.9(-2.9,1.1)$ & 0.134 \\
\hline Z-score of tBMD & $0.1(-1.2,1.2)$ & $-0.2(-2.0,1.4)$ & 0.228 & $-0.5(-1.5,1.1)$ & $-0.5(-2.5,1.2)$ & 0.442 \\
\hline
\end{tabular}


A
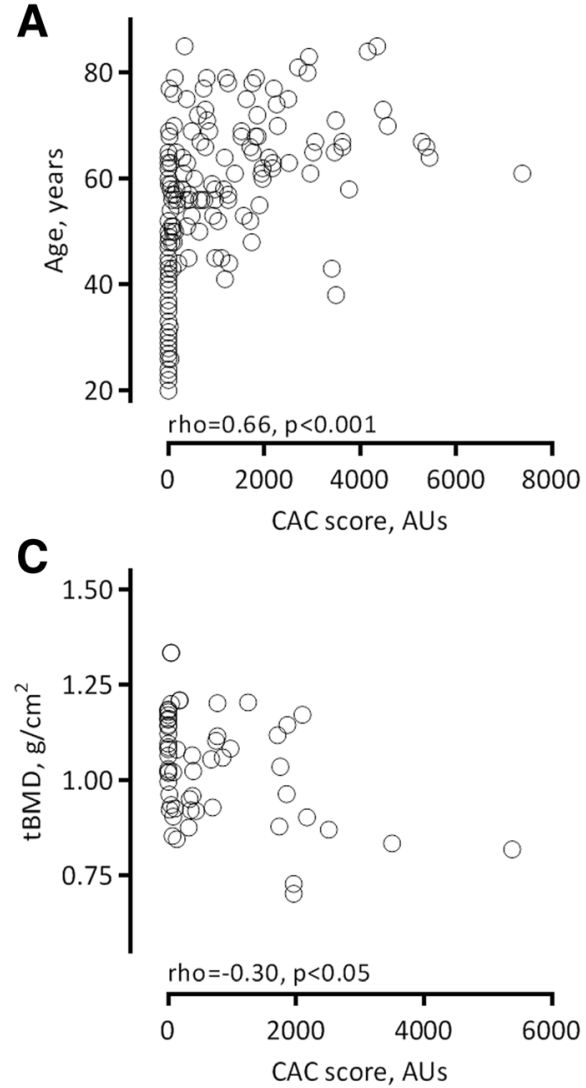

B

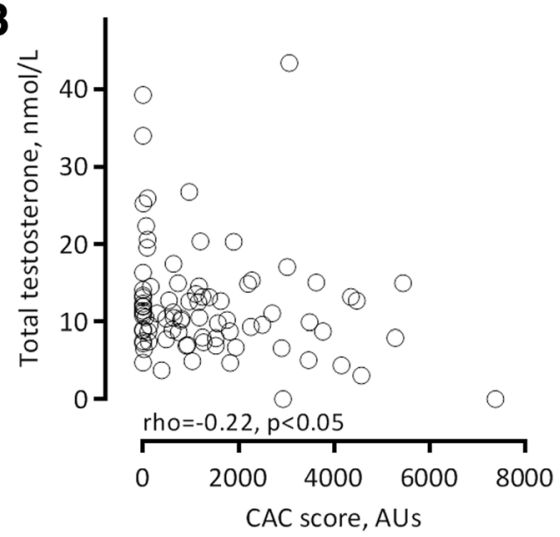

D

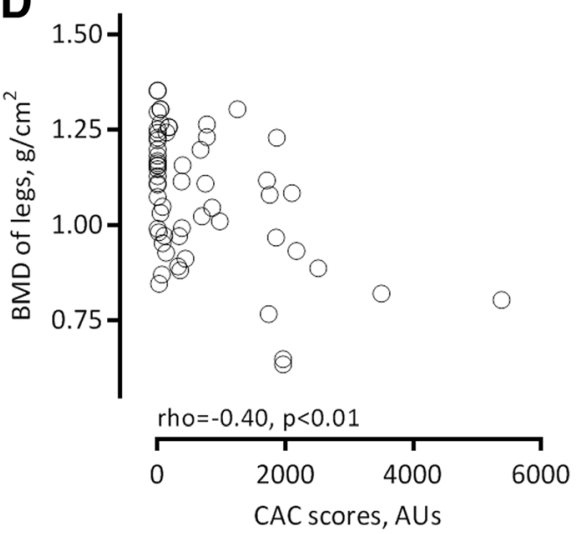

Fig. 3 CAC score in ESRD patients associated with: age ( $n=174, \mathbf{a})$, total testosterone in men $(n=95, \mathbf{b})$, and - in women only - with total BMD $(n=64, \mathbf{c})$ and BMD at legs $(n=64, \mathbf{d})$

DXA may be influenced by signals from a calcified aorta [7], we presume that the value for spine BMD may be overestimated.

Our report on a significant inverse relationship between BMD and CAC in females only accords with previous studies [39, 40]. Bakhireva et al. [41] reported

Table 3 Spearman's Rho correlations of CAC score and BMD at sub-regions

\begin{tabular}{lll}
\hline & \multicolumn{2}{c}{ CAC score Rho correlations } \\
\cline { 2 - 3 } & Female & Male \\
\hline Head, g/cm & -0.16 & $-0.21^{*}$ \\
Arms, g/cm & $-0.27^{*}$ & -0.07 \\
Legs, g/cm & $-0.40^{* *}$ & -0.07 \\
Trunk, g/cm & -0.16 & 0.01 \\
Ribs, g/cm & -0.16 & -0.01 \\
Pelvis, g/cm & -0.20 & -0.08 \\
Spine, g/ $/ \mathrm{cm}^{2}$ & -0.06 & 0.14 \\
tBMD, g/cm & $-0.30^{*}$ & -0.08 \\
T-score of tBMD & $-0.35^{* *}$ & -0.10 \\
Z-score of tBMD & $-0.26^{*}$ & -0.02 \\
\hline
\end{tabular}

that higher BMD was associated with reduced CAC of all skeletal sites after adjustment for confounders in women using hormone therapy but not in males, nor in females not on HT. Kim et al. [18] also reported that a significant relationship between BMD and CAC existed only in women. In accordance, Campos-Obando et al. [19] found significant associations between BMD loss and follow-up CAC only in the subgroup of women with lower estradiol levels. Kiel et al. [42] from the Framingham cohort reported a lack of association between BMD loss and aortic calcification in men. Jensky et al. [43] found the association of BMD and CAC to be stronger in women without dyslipidemia in the multi-ethnic study of

Table 4 Muliple regression for 1-SD (1057 AUs) higher CAC score in 64 female ESRD patients: BMD at legs

\begin{tabular}{llll}
\hline $\begin{array}{l}\text { Multivariate model } \\
\left(n=64, \text { adjusted } r^{2}=0.17\right)\end{array}$ & Beta & Standard error & $P$ value \\
\hline Higher age (per SD, 16 years) & 0.07 & 0.12 & 0.58 \\
Higher hsCRP (per SD, 10.5 mmol/L) & 0.15 & 0.12 & 0.19 \\
Diabetes (yes/no) & 0.23 & 0.27 & 0.06 \\
Higher BMD at legs (per SD, $\left.0.17 \mathrm{~g} / \mathrm{cm}^{2}\right)$ & -0.28 & 0.12 & 0.02 \\
\hline
\end{tabular}


Table 5 Muliple regression for 1-SD (1057 AUs) higher CAC score in 64 female ESRD patients: tBMD

\begin{tabular}{llll}
\hline $\begin{array}{l}\text { Multivariate model } \\
\left(n=64 \text {, adjusted } r^{2}=0.16\right)\end{array}$ & Beta & Standard error & $P$ value \\
\hline Higher age (per SD, 16 years) & 0.06 & 0.12 & 0.62 \\
Higher hsCRP (per SD, $10.5 \mathrm{mmol} / \mathrm{L})$ & 0.16 & 0.12 & 0.17 \\
Diabetes (yes/no) & 0.27 & 0.27 & 0.02 \\
Higher tBMD (per SD, $0.13 \mathrm{~g} / \mathrm{cm}^{2}$ ) & -0.27 & 0.12 & 0.03
\end{tabular}

Abbreviations: GLM generalized linear model, CAC coronary artery calcification, $h s C R P$ high sensitivity C-reactive protein, $t B M D$ total bone mineral density

atherosclerosis cohort. The independent inverse association between BMD and CAC observed in females only suggests the link between arterial calcification and bone mineralization are mediated by sex hormones.

In nondialysis male CKD patients, the reduction in testosterone levels observed with progressive CKD was inversely associated with endothelial dysfunction and exacerbated the risk of future cardiac events [44]. Testosterone concentrations inversely correlate with CVD related and all-caused mortality in CKD patients [45]. Studies investigating possible links of testosterone with vascular calcification have been inconsistent. Whereas two studies show no relationship in males and females [46, 47]; Phillips et al. [48] found in women an inverse relationship between free testosterone and severity of coronary disease. Increasing evidences points towards a protective effect (low testosterone levels associated with high cardiovascular risk) in both females [49-51] and males [52-55]. For the first time, we report on a significant inverse relationship between total testosterone and CAC score among the men. Testosterone has positive effects on endothelium by directly stimulating endothelium-derived nitric oxide [56] and stimulate endothelial progenitor cells, which play a key role in endothelial

Table 6 Muliple regression for 1-SD (1484 AUs) higher CAC score in 110 male ESRD patients: BMD at legs

\begin{tabular}{|c|c|c|c|c|c|c|}
\hline \multirow[t]{2}{*}{$\begin{array}{l}\text { Multivariate } \\
\text { model (GLM) }\end{array}$} & \multicolumn{3}{|c|}{$\begin{array}{l}\text { Model } 1(n=110 \\
\left.\text { adjusted } r^{2}=0.40\right)\end{array}$} & \multicolumn{3}{|c|}{$\begin{array}{l}\text { Model } 2(n=95 \\
\left.\text { adjusted } r^{2}=0.40\right)\end{array}$} \\
\hline & Beta & $\begin{array}{l}\text { Standard } \\
\text { error }\end{array}$ & $P$ value & Beta & $\begin{array}{l}\text { Standard } \\
\text { error }\end{array}$ & $P$ value \\
\hline $\begin{array}{l}\text { Higher age } \\
\text { (per SD, 16 years) }\end{array}$ & 0.61 & 0.07 & $<0.01$ & 0.62 & 0.07 & $<0.01$ \\
\hline $\begin{array}{l}\text { Higher hsCRP } \\
\text { (per SD, } 11.8 \mathrm{mmol} / \mathrm{L} \text { ) }\end{array}$ & 0.07 & 0.07 & 0.39 & 0.07 & 0.07 & 0.43 \\
\hline Diabetes (yes/no) & 0.11 & 0.15 & 0.16 & 0.11 & 0.17 & 0.18 \\
\hline $\begin{array}{l}\text { Higher BMD at legs } \\
\text { (per SD, } 0.16 \mathrm{~g} / \mathrm{cm}^{2} \text { ) }\end{array}$ & 0.12 & 0.07 & 0.13 & 0.16 & 0.07 & 0.05 \\
\hline $\begin{array}{l}\text { Higher total } \\
\text { testoterone } \\
\text { (per SD, } 7.1 \mathrm{nmol} / \mathrm{L} \text { ) }\end{array}$ & & & & 0.02 & 0.08 & 0.78 \\
\hline
\end{tabular}

Table 7 Muliple regression for 1-SD (1484 AUs) higher CAC score in 110 male ESRD patients: tBMD

\begin{tabular}{|c|c|c|c|c|c|c|}
\hline \multirow[t]{2}{*}{$\begin{array}{l}\text { Multivariate } \\
\text { model (GLM) }\end{array}$} & \multicolumn{3}{|c|}{$\begin{array}{l}\text { Model } 1(n=110 \\
\left.\text { adjusted } r^{2}=0.40\right)\end{array}$} & \multicolumn{3}{|c|}{$\begin{array}{l}\text { Model } 2(n=95 \\
\left.\text { adjusted } r^{2}=0.40\right)\end{array}$} \\
\hline & Beta & $\begin{array}{l}\text { Standard } \\
\text { error }\end{array}$ & $P$ value & Beta & $\begin{array}{l}\text { Standard } \\
\text { error }\end{array}$ & $P$ value \\
\hline $\begin{array}{l}\text { Higher age } \\
\text { (per SD, 16years) }\end{array}$ & 0.61 & 0.07 & $<0.01$ & 0.61 & 0.08 & $<0.01$ \\
\hline $\begin{array}{l}\text { Higher hsCRP } \\
\text { (per SD, } 11.8 \mathrm{mmol} / \mathrm{L})\end{array}$ & 0.06 & 0.07 & 0.41 & 0.06 & 0.07 & 0.45 \\
\hline Diabetes (yes/no) & 0.10 & 0.15 & 0.21 & 0.10 & 0.17 & 0.22 \\
\hline $\begin{array}{l}\text { Higher tBMD } \\
\text { (per SD, } 0.12 \mathrm{~g} / \mathrm{cm}^{2} \text { ) }\end{array}$ & 0.10 & 0.07 & 0.19 & 0.13 & 0.07 & 0.11 \\
\hline $\begin{array}{l}\text { Higher total } \\
\text { testosterone } \\
\text { (per SD, } 7.1 \mathrm{nmol} / \mathrm{L} \text { ) }\end{array}$ & & & & 0.03 & 0.08 & 0.71 \\
\hline
\end{tabular}

Abbreviations: GLM, generalized linear model, $C A C$ coronary artery calcification, $h s C R P$ high sensitivity C-reactive protein, $t B M D$ total bone mineral density

repair [57]. Furthermore, while testosterone has anabolic effects, including promotion of muscle strength and muscle mass, bone density and maturation, women have much lower levels of testosterone than men. On the other hand, deficiency of estrogen, whose beneficial effects on the coronary arteries have been reported only in women [58], has been proposed to be a common mediator in the emergence of CVD and bone loss in postmenopausal women [59]. The relative contributions of estrogen and testosterone to skeletal homeostasis that may initiate bone loss are still uncertain [60]. It is can be speculated that dysregulation of testosterone and testosterone deficiency may have accounted for the observed sex difference with inverse association of BMD with CAC only in women while in men - when testosterone was added into the model - higher BMD associated with higher CAC. This intriguing observation seems to provide further support for sex differentiating links between hormonal status, BMD and vascular calcification.

This study should be interpreted with some limitations. First, no conclusions can be made regarding causality because of the observational design of the study. Second, due to the limited number of participants and the risk of type- 2 statistical error, our findings should be interpreted with caution. Third, there are limitations of the methods applied: for measurement of BMD, DXA may not be an ideal method, since it cannot distinguish between bone mineral content and extra-osseous calcifications; and, use of CT for measurement of CAC could not distinguish medial from intimal calcification [15]. Fourth, data on hormone replacement therapy, menopause and sex hormone levels in women were not available. 


\section{Conclusions}

In conclusion, lower BMD (tBMD and BMD of sub-regions, in particular the sub-region of legs) was associated with higher CAC scores independently, but only in female ESRD patients. Our main finding that low BMD of legs significantly associates with high CAC scores even when adjusted for age, diabetes and hsCRP should encourage further studies to elucidate the specific mechanisms linking regional differences in bone metabolism and gender differences to vascular calcification.

\section{Additional file}

Additional file 1: Table S1. Clinical and biochemical characteristics for the total 174 ESRD patients and for two subgroups based on median total body BMD (tBMD) level. Data presented as median (range of 10th - 90th percentile) or percentage. Abbreviations: BP, blood pressure; HDL, high-density lipoprotein; hsCRP, high sensitivity C-reactive protein; TNF, tumor necrosis factor; IL-6, interleukin-6; PTX, pentraxin; iPTH, intact parathyroid hormone; CAC, coronary artery calcification; tBMD, total bone mineral density. ${ }^{a} ; n=151,{ }^{b} ; n=166,{ }^{c} ; n=135 ;{ }^{d} ; n=95 ;{ }^{~}$; $n=130, f ; n=105$. (DOC $52 \mathrm{~kb}$ )

\section{Abbreviations}

AUC: Area under the curve; AUs: Agatston units; BMD: Bone mineral density; BMI: Body mass index; BP: Blood pressures; CAC: Coronary artery calcification; CKD: Chronic kidney disease; CKD-MBD: Chronic kidney disease - mineral and bone disorders; CT: Computed tomography; CVD: Cardiovascular disease; DXA: Dual-energy X-ray absorptiometry; ESRD: End-stage renal disease; GE: General Electric; GLM: Generalized linear model; HDL: High density lipoprotein; hsCRP: High-sensitivity C-reactive protein; IL-6: Interleukin-6; iPTH: Intact parathyroid hormone; LD-Rtx: Living donor kidney transplant; PD: Peritoneal dialysis; PTX3: Pentraxin-3; ROC: Receiver operating characteristics; tBMD: Total body BMD; TNF: Tumour necrosis factor

\section{Acknowledgments}

We thank the patients who participated in the study. We are grateful to all those who carried out the extensive clinical and laboratory work in the current study in the clinical investigational unit $(\mathrm{KBC})$ and the renal laboratory at Department of Renal Medicine, Karolinska University Hospital.

\section{Funding}

Zhimin Chen received a scholarship from the China Scholarship Council and research benefited by support from Zhejiang Medical and Health Science and Technology Project (2019RC037) which played an important role in the analysis and interpretation of data and in writing and revising the manuscript. Peter Stenvinkel's research benefited by support from Swedish Medical Research Council (K2014-65X-15320-10-3), Njurfonden and Westmans Foundation which played the role of the design of the study and collection of the data for the manuscript.

\section{Availability of data and materials}

Not applicable.

The cohort data we used contained identifying/confidential patient data which we wish should not be shared.

\section{Authors' contributions}

ZC conceived the study, analysis and interpretation of data, and drafted the manuscript; AQ was was accountable for all aspects of the analysis of data and participated in the design of the study; TB participated in the design of the study and interpretation of data; JP participated in acquisition and interpretation of data; $\mathrm{MH}$ participated in the design of the study and acquisition of data; PB participated in the design of the study and acquisition of data; $\mathrm{OH}$ participated in the design of the study and acquisition of data; BL participated in the design of the study, helped to draft the manuscript, and revised it critically for important intellectual content; PS was involved in the design of the study and participated in the general supervision of the work and interpretation of data. All authors read and approved the final manuscript.

\section{Ethics approval and consent to participate}

The Ethics Committee of Karolinska University Hospital Huddinge approved the study protocols. Informed consent in written format was obtained from all patients before their inclusion in the study.

\section{Consent for publication}

Not applicable.

\section{Competing interests}

Baxter Novum is a result of a grant from Baxter Healthcare to Karolinska Institutet. Baxter Healthcare employs Bengt Lindholm.

The authors declare that they have no competing interests.

\section{Publisher's Note}

Springer Nature remains neutral with regard to jurisdictional claims in published maps and institutional affiliations.

\section{Author details}

${ }^{1}$ Kidney Disease Center, The First Affiliated Hospital, College of Medicine, Zhejiang University, Hangzhou, China. ${ }^{2}$ Division of Renal Medicine and Baxter Novum, Department of Clinical Sciences, Intervention and Technology, Karolinska Institutet, Stockholm, Sweden. ${ }^{3}$ Division of Medical Imaging and Technology, Department of Clinical Science, Intervention and Technology, Karolinska Institutet, and Department of Radiology, Karolinska University Hospital, Huddinge, Stockholm, Sweden.

Received: 16 September 2018 Accepted: 28 January 2019

Published online: 18 February 2019

\section{References}

1. Menon V, Gul A, Sarnak MJ. Cardiovascular risk factors in chronic kidney disease. Kidney Int. 2005;68(4):1413-8.

2. Matsuoka M, Iseki K, Tamashiro M, Fujimoto N, Higa N, Touma T, Takishita S. Impact of high coronary artery calcification score (CACS) on survival in patients on chronic hemodialysis. Clin Exp Nephrol. 2004;8(1):54-8.

3. Block GA, Raggi P, Bellasi A, Kooienga L, Spiegel DM. Mortality effect of coronary calcification and phosphate binder choice in incident hemodialysis patients. Kidney Int. 2007;71(5):438-41.

4. Detrano R, Guerci AD, Carr JJ, Bild DE, Burke G, Folsom AR, Liu K, Shea S, Szklo M, Bluemke DA, et al. Coronary calcium as a predictor of coronary events in four racial or ethnic groups. N Engl J Med. 2008;358(13):1336-45

5. Greenland P, LaBree L, Azen SP, Doherty TM, Detrano RC. Coronary artery calcium score combined with Framingham score for risk prediction in asymptomatic individuals. JAMA. 2004;291(2):210-5.

6. Trivedi DP, Khaw KT. Bone mineral density at the hip predicts mortality in elderly men. Osteoporos Int. 2001;12(4):259-65.

7. Disthabanchong S, Jongjirasiri S, Adirekkiat S, Sumethkul V, Ingsathit A, Domrongkitchaiporn S, Phakdeekitcharoen B, Kantachuvesiri S, Kitiyakara C. Low hip bone mineral density predicts mortality in maintenance hemodialysis patients: a five-year follow-up study. Blood Purif. 2014;37(1):33-8.

8. Tanko LB, Christiansen C, Cox DA, Geiger MJ, McNabb MA, Cummings SR. Relationship between osteoporosis and cardiovascular disease in postmenopausal women. J Bone Miner Res. 2005;20(11):1912-20.

9. Toussaint ND, Lau KK, Strauss BJ, Polkinghorne KR, Kerr PG. Associations between vascular calcification, arterial stiffness and bone mineral density in chronic kidney disease. Nephrol Dial Transplant. 2008;23(2):586-93.

10. Ketteler M, Biggar PH. Review article: getting the balance right: assessing causes and extent of vascular calcification in chronic kidney disease. Nephrology. 2009;14(4):389-94.

11. Shao JS, Cai J, Towler DA. Molecular mechanisms of vascular calcification: lessons learned from the aorta. Arterioscler Thromb Vasc Biol. 2006;26(7): 1423-30.

12. Johnson RC, Leopold JA, Loscalzo J. Vascular calcification: pathobiological mechanisms and clinical implications. Circ Res. 2006:99(10):1044-59.

13. Barengolts El, Berman M, Kukreja SC, Kouznetsova T, Lin C, Chomka EV. Osteoporosis and coronary atherosclerosis in asymptomatic postmenopausal women. Calcif Tissue Int. 1998;62(3):209-13. 
14. Frye MA, Melton L, Bryant SC, Fitzpatrick LA, Wahner HW, Schwartz RS, Riggs BL. Osteoporosis and calcification of the aorta. Bone Miner. 1992;19(2):185-94.

15. Braun J, Oldendorf M, Moshage W, Heidler R, Zeitler E, Luft FC. Electron beam computed tomography in the evaluation of cardiac calcification in chronic dialysis patients. Am J Kidney Dis. 1996;27(3):394-401.

16. Kirkpantur A, Altun B, Hazirolan T, Akata D, Arici M, Kirazli S, Turgan C Association among serum Fetuin-a level, coronary artery calcification, and bone mineral densitometry in maintenance hemodialysis patients. Artif Organs. 2009;33(10):844-54.

17. Sinnott B, Syed I, Sevrukov A, Barengolts E. Coronary calcification and osteoporosis in men and postmenopausal women are independent processes associated with aging. Calcif Tissue Int. 2006;78(4):195-202.

18. Kim KI, Suh JW, Choi SY, Chang HJ, Choi DJ, Kim CH, Oh BH. Is reduced bone mineral density independently associated with coronary artery calcification in subjects older than 50 years? J Bone Miner Metab. 2011;29(3):369-76.

19. Campos-Obando N, Kavousi M, Roeters van Lennep JE, Rivadeneira F, Hofman A, Uitterlinden AG, Franco OH, Zillikens MC. Bone health and coronary artery calcification: the Rotterdam study. Atherosclerosis. 2015; 241(1):278-83.

20. Shen H, Bielak LF, Streeten EA, Ryan KA, Rumberger JA, Sheedy PF 2nd, Shuldiner AR, Peyser PA, Mitchell BD. Relationship between vascular calcification and bone mineral density in the old-order Amish. Calcif Tissue Int. 2007:80(4):244-50.

21. Barreto DV, Barreto FC, Carvalho AB, Cuppari L, Cendoroglo M, Draibe SA, Moyses RM, Neves KR, Jorgetti V, Blair A, et al. Coronary calcification in hemodialysis patients: the contribution of traditional and uremia-related risk factors. Kidney Int. 2005;67(4):1576-82.

22. Cejka D, Weber M, Diarra D, Reiter T, Kainberger F, Haas M. Inverse association between bone microarchitecture assessed by HR-pQCT and coronary artery calcification in patients with end-stage renal disease. Bone. 2014;64:33-8.

23. Malluche HH, Blomquist G, Monier-Faugere MC, Cantor TL, Davenport DL. High parathyroid hormone level and osteoporosis predict progression of coronary artery calcification in patients on dialysis. J Am Soc Nephrol. 2015; 26(10):2534-44.

24. Persy V, D'Haese P. Vascular calcification and bone disease: the calcification paradox. Trends Mol Med. 2009;15(9):405-16.

25. Van Langendonck L, Claessens AL, Lefevre J, Thomis M, Philippaerts R, Delvaux K, Lysens R, Vanden Eynde B, Beunen G. Association between bone mineral density (DXA), body structure, and body composition in middleaged men. Am J Hum Biol. 2002;14(6):735-42.

26. Agatston AS, Janowitz WR, Hildner FJ, Zusmer NR, Viamonte M Jr, Detrano R. Quantification of coronary artery calcium using ultrafast computed tomography. J Am Coll Cardiol. 1990;15(4):827-32.

27. Chen Z, Sun J, Haarhaus M, Barany P, Wennberg L, Ripsweden J, Brismar TB, Lindholm B, Wernerson A, Soderberg $M$, et al. Bone mineral density of extremities is associated with coronary calcification and biopsy-verified vascular calcification in living-donor renal transplant recipients. J Bone Miner Metab. 2016.

28. Chen Z, Qureshi AR, Ripsweden J, Wennberg L, Heimburger O, Lindholm B, Barany P, Haarhaus M, Brismar TB, Stenvinkel P. Vertebral bone density associates with coronary artery calcification and is an independent predictor of poor outcome in end-stage renal disease patients. Bone. 2016;92:50-7.

29. Chen Z, Qureshi AR, Parini P, Hurt-Camejo E, Ripsweden J, Brismar TB, Barany $P$, Jaminon AM, Schurgers $\sqcup$, Heimburger $O$, et al. Does statins promote vascular calcification in chronic kidney disease? Eur J Clin Investig. 2017:47(2):137-48

30. He ZX, Hedrick TD, Pratt CM, Verani MS, Aquino V, Roberts R, Mahmarian JJ. Severity of coronary artery calcification by electron beam computed tomography predicts silent myocardial ischemia. Circulation. 2000;101(3):244-51.

31. Qureshi AR, Olauson H, Witasp A, Haarhaus M, Brandenburg V, Wernerson A, Lindholm B, Soderberg M, Wennberg L, Nordfors L, et al. Increased circulating sclerostin levels in end-stage renal disease predict biopsy-verified vascular medial calcification and coronary artery calcification. Kidney Int. 2015;88(6):1356-64.

32. Vogt MT, San Valentin R, Forrest KY, Nevitt MC, Cauley JA. Bone mineral density and aortic calcification: the study of osteoporotic fractures. J Am Geriatr Soc. 1997;45(2):140-5.

33. Farhat GN, Cauley JA, Matthews KA, Newman AB, Johnston J, Mackey R, Edmundowicz D, Sutton-Tyrrell K. Volumetric BMD and vascular calcification in middle-aged women: the study of Women's health across the nation. J Bone Miner Res. 2006;21(12):1839-46.
34. Banks LM, Lees B, MacSweeney JE, Stevenson JC. Effect of degenerative spinal and aortic calcification on bone density measurements in postmenopausal women: links between osteoporosis and cardiovascular disease? Eur J Clin Investig. 1994;24(12):813-7.

35. Uyama O, Yoshimoto Y, Yamamoto Y, Kawai A. Bone changes and carotid atherosclerosis in postmenopausal women. Stroke. 1997:28(9):1730-2.

36. Toussain ND, Lau KK, Strauss BJ, Polkinghorne KR, Kerr PG. Associations between vascular calcification, arterial stiffness and bone mineral density in chronic kidney disease. Nephrol Dial Transpl. 2008;23(2):586-93.

37. Kooman JP, Kotanko P, Schols AM, Shiels PG, Stenvinkel P. Chronic kidney disease and premature ageing. Nat Rev Nephrol. 2014;10(12):732-42.

38. Kohno K, Inaba M, Okuno S, Maeno Y, Maekawa K, Yamakawa T, Ishimura E, Nishizawa $Y$. Association of reduction in bone mineral density with mortality in male hemodialysis patients. Calcif Tissue Int. 2009;84(3):180-5.

39. Choi SH, An JH, Lim S, Koo BK, Park SE, Chang HJ, Choi SI, Park YJ, Park KS, Jang $\mathrm{HC}$, et al. Lower bone mineral density is associated with higher coronary calcification and coronary plaque burdens by multidetector row coronary computed tomography in pre- and postmenopausal women. Clin Endocrinol. 2009;71(5):644-51.

40. Hyder JA, Allison MA, Wong N, Papa A, Lang TF, Sirlin C, Gapstur SM, Ouyang P, Carr JJ, Criqui MH. Association of coronary artery and aortic calcium with lumbar bone density: the MESA abdominal aortic calcium study. Am J Epidemiol. 2009;169(2):186-94.

41. Bakhireva LN, Barrett-Connor EL, Laughlin GA, Kritz-Silverstein D. Differences in association of bone mineral density with coronary artery calcification in men and women: the rancho Bernardo study. Menopause. 2005;12(6):691-8.

42. Kiel DP, Kauppila LI, Cupples LA, Hannan MT, O'Donnell CJ, Wilson PW. Bone loss and the progression of abdominal aortic calcification over a 25 year period: the Framingham heart study. Calcif Tissue Int. 2001;68(5):271-6.

43. Jensky NE, Hyder JA, Allison MA, Wong N, Aboyans V, Blumenthal RS, Schreiner P, Carr JJ, Wassel CL, IX JH, et al. The association of bone density and calcified atherosclerosis is stronger in women without dyslipidemia: the multi-ethnic study of atherosclerosis. J Bone Miner Res. 2011;26(11):2702-9.

44. Yilmaz Ml, Sonmez A, Qureshi AR, Saglam M, Stenvinkel P, Yaman H, Eyileten T, Caglar K, Oguz Y, Taslipinar A, et al. Endogenous testosterone, endothelial dysfunction, and cardiovascular events in men with nondialysis chronic kidney disease. Clin J Am Soc Nephrol. 2011;6(7):1617-25.

45. Carrero JJ, Qureshi AR, Parini P, Arver S, Lindholm B, Barany P, Heimburger $\mathrm{O}$, Stenvinkel $\mathrm{P}$. Low serum testosterone increases mortality risk among male dialysis patients. J Am Soc Nephrol. 2009;20(3):613-20.

46. Calderon-Margalit R, Schwartz SM, Wellons MF, Lewis CE, Daviglus ML, Schreiner PJ, Williams OD, Sternfeld B, Carr JJ, O'Leary DH, et al. Prospective association of serum androgens and sex hormone-binding globulin with subclinical cardiovascular disease in young adult women: the "coronary artery risk development in young adults" women's study. J Clin Endocrinol Metab. 2010;95(9):4424-31

47. Michos ED, Vaidya D, Gapstur SA, Schreiner PJ, Golden SH, Wong ND, Criqui $\mathrm{MH}$, Ouyang P. Sex hormones, sex hormone binding globulin, and abdominal aortic calcification in women and men in the multi-ethnic study of atherosclerosis (MESA). Atherosclerosis. 2008;200(2):432-8.

48. Phillips $G B$, Pinkernell $B H$, Jing TY. Relationship between serum sex hormones and coronary artery disease in postmenopausal women. Arterioscler Thromb Vasc Biol. 1997;17(4):695-701.

49. Bernini GP, Sgro M, Moretti A, Argenio GF, Barlascini CO, Cristofani R, Salvett A. Endogenous androgens and carotid intimal-medial thickness in women. J Clin Endocrinol Metab. 1999;84(6):2008-12.

50. Montalcini T, Gorgone G, Gazzaruso C, Sesti G, Perticone F, Pujia A. Role of endogenous androgens on carotid atherosclerosis in non-obese postmenopausal women. Nutr Metab Cardiovasc Dis. 2007;17(10):705-11.

51. Ouyang P, Vaidya D, Dobs A, Golden SH, Szklo M, Heckbert SR, Kopp P, Gapstur SM. Sex hormone levels and subclinical atherosclerosis in postmenopausal women: the multi-ethnic study of atherosclerosis. Atherosclerosis. 2009;204(1):255-61.

52. Park BJ, Shim JY, Lee YJ, Lee JH, Lee HR. Inverse relationship between bioavailable testosterone and subclinical coronary artery calcification in non-obese Korean men. Asian J Androl. 2012;14(4):612-5.

53. Malkin CJ, Pugh PJ, Morris PD, Asif S, Jones TH, Channer KS. Low serum testosterone and increased mortality in men with coronary heart disease. Heart. 2010;96(22):1821-5.

54. Khaw KT, Dowsett M, Folkerd E, Bingham S, Wareham N, Luben R, Welch A Day $\mathrm{N}$. Endogenous testosterone and mortality due to all causes, 
cardiovascular disease, and cancer in men: European prospective investigation into cancer in Norfolk (EPIC-Norfolk) prospective population study. Circulation. 2007;116(23):2694-701.

55. Muller M, van den Beld AW, Bots ML, Grobbee DE, Lamberts SWJ, van der Schouw YT. Endogenous sex hormones and progression of carotid atherosclerosis in elderly men. Circulation. 2004;109(17):2074-9.

56. Yue P, Chatterjee K, Beale C, Poolewilson PA, Collins P. Testosterone relaxes rabbit coronary-arteries and aorta. Circulation. 1995;91(4):1154-60.

57. Foresta C, Zuccarello D, De Toni L, Garolla A, Caretta N, Ferlin A. Androgens stimulate endothelial progenitor cells through an androgen receptormediated pathway. Clin Endocrinol. 2008;68(2):284-9.

58. Collins P, Rosano GMC, Sarrel PM, Ulrich L, Adamopoulos S, Beale CM, Mcneill JG, Poolewilson PA. 17-Beta-estradiol attenuates acetylcholineinduced coronary arterial constriction in women but not men with coronary heart-disease. Circulation. 1995:92(1):24-30.

59. Manson JE, Allison MA, Rossouw JE, Carr JJ, Langer RD, Hsia J, Kuller LH, Cochrane BB, Hunt JR, Ludlam SE, et al. Estrogen therapy and coronaryartery calcification. New Engl J Med. 2007;356(25):2591-602.

60. Finkelstein JS, Lee H, Leder BZ, Burnett-Bowie SA, Goldstein DW, Hahn CW Hirsch SC, Linker A, Perros N, Servais AB, et al. Gonadal steroid-dependent effects on bone turnover and bone mineral density in men. J Clin Invest. 2016;126(3):1114-25.

Ready to submit your research? Choose BMC and benefit from:

- fast, convenient online submission

- thorough peer review by experienced researchers in your field

- rapid publication on acceptance

- support for research data, including large and complex data types

- gold Open Access which fosters wider collaboration and increased citations

- maximum visibility for your research: over $100 \mathrm{M}$ website views per year

At BMC, research is always in progress.

Learn more biomedcentral.com/submissions 